\title{
ANALISIS BIAYA-VOLUME-LABA UNTUK PERENCANAAN LABA OPERASI
}

\author{
Engelwati Gani \\ Accounting and Finance Department, Faculty of Economic and Comunication, BINUS University \\ Jln. K. H. Syahdan No. 9, Palmerah, Jakarta Barat 11480 \\ engelwatigani@yahoo.com
}

\begin{abstract}
This study conducted cost-volume-profit analysis of the company. A maximum profit can be obtained by analyzing sales volume and product mix to be sold. So that, the cost-volume-profit analysis can be used as a planning strategy of the company's operations profit. To do so, semivariable costs must be separated into variable and static costs. After that the breakeven point can be calculated. By knowing the breakeven point, operations profit planning expected can be made. Research used qualitative method with direct contact by interviewing the company and indirect contact by observing the company's profit-loss financial statements from 2008 to 2011. PT SD Textile is a manufacturing company engaged in the manufacture of damask, sheet and towel. Conditions of sales and the cost of sales have increased in the period of 2008 to 2010 and have decreased in the period of 2011; while the operations expenses have increased in the period 2008 to 2011. The increase and decrease in sales, the cost of sales and operations expenses have a direct impact on the operations profit. The operations profit increased in the period of 2008 to 2009 and decreased in the period of 2010 and increased again during the period of 2011. Given the situasion, it is very important for PT SD Textile to do operations profit planning with attention to sales planning and costs in order to deliver the maximum profit.
\end{abstract}

Keywords: cost-volume-profit analysis, operations profit, breakeven point

\begin{abstract}
ABSTRAK
Penelitian dilakukan untuk menganalisis biaya-volume-laba perusahaan. Sementara laba maksimum dapat diperoleh dengan menganalisis volume penjualan dan bauran produk yang harus dijual. Dengan demikian, analisis biaya-volume-laba dapat digunakan sebagai strategi perencanaan laba operasi perusahaan. Untuk itu harus dipisahkan biaya semivariabel menjadi biaya variabel dan biaya tetap, setelah itu dapat dihitung titik impas. Dengan mengetahui titik impas, maka dapat dibuat rencana laba operasi yang diharapkan. Metode penelitian adalah metode kualitatif dengan kontak langsung berupa wawancara dan tidak langsung dari pengamatan menggunakan laporan keuangan khususnya laporan laba-rugi perusahaan periode 2008 sampai 2011. PT SD Textile merupakan perusahaan manufaktur yang bergerak di bidang tekstil dengan memproduksi damask, sheet, dan towel. Kondisi penjualan dan harga pokok penjualan mengalami peningkatan pada periode 2008 sampai periode 2010 dan mengalami penurunan pada periode 2011; sedangkan beban operasi perusahaan mengalami peningkatan pada periode 2008 sampai periode 2011. Peningkatan dan penurunan penjualan, harga pokok penjulan, dan beban operasi akan berdampak langsung pada laba operasi yang dihasilkan. Laba operasi yang dihasilkan mengalami peningkatan pada periode 2008 sampai periode 2009 dan mengalami penurunan pada periode 2010 serta mengalami peningkatan kembali pada periode 2011. Melihat situasi tersebut, sangat penting bagi PT SD Textile untuk melakukan perencanaan laba operasi dengan memerhatikan perencanaan penjualan serta biaya agar memberikan laba yang maksimum.
\end{abstract}

Kata kunci: analisis biaya-volume-laba, laba operasi, titik impas 


\section{PENDAHULUAN}

Tujuan perusahaan didirikan adalah untuk menghasilkan barang dan jasa yang diperlukan oleh masyarakat. Sementara bagi perusahaan adalah untuk memperoleh laba maksimum dan kinerja perusahaan yang baik sekarang dan masa depan. Besar kecil laba yang diperoleh perusahaan merupakan tolok ukur berhasil atau tidak manajemen dalam mengelola perusahaan. Oleh karena itu, strategi perencanaan laba operasi yang dapat mengombinasikan kedua tujuan tersebut diperlukan. Salah satu strategi yang digunakan adalah analisis biaya-volume-laba untuk perencanaan laba.

Hilton (2002:320) memberikan definisi analisis biaya-volume-laba: "Cost-volume-profit (CVP) analysis is a study of the relationships between sales volume, expenses, revenue, and profit." Carter dan Usry (2005:273) menyatakan: "Tujuan CVP adalah untuk menentukan volume penjualan dan bauran produk yang diperlukan untuk mencapai target laba (laba sama dengan nol dalam kasus analisis titik impas)." Kemudian Shim dan Siegel (2009:3) memberikan definisi: "Planning is determining the activities to be accomplished to achieve objectives and goals."

Untuk mencapai laba maksimum, manajemen perusahaan dapat melakukan beberapa langkah, yaitu menekan biaya produksi maupun operasi dengan mempertahankan harga jual dan volume penjualan, menentukan harga jual sesuai dengan laba yang diharapkan, dan meningkatkan volume penjualan sebesar mungkin. Ketiga langkah tersebut tidak dapat dilakukan secara terpisah karena mempunyai hubungan yang saling berkaitan, yaitu biaya menentukan harga jual, harga jual menentukan volume penjualan, volume penjualan memengaruhi volume produksi, dan volume produksi memengaruhi biaya. PT SD Textile merupakan perusahaan manufaktur yang bergerak di bidang tekstil dengan memproduksi damask, sheet, dan towel.

\section{METODE PENELITIAN}

Karakteristik riset ini adalah sebagai berikut. Pertama, jenis riset adalah riset eksploratoria (kualitatif, naturalis). Kedua, dimensi waktu riset adalah time-series yaitu laporan keuangan khususnya laporan laba-rugi periode 2008 sampai 2011. Ketiga, kedalaman riset adalah studi kasus pada PT SD Textile. Keempat, metode pengumpulan data berupa kontak langsung dan kontak tidak langsung, berupa penelitian lapangan yaitu wawancara (interview) secara langsung kepada pihak perusahaan yang terkait untuk memperoleh data dan informasi yang berkaitan dengan penelitian. Kontak tidak langsung berupa pengamatan (observation) dengan mengadakan peninjauan atau pengamatan langsung ke lokasi perusahaan baik mengenai keadaan maupun kegiatan perusahaan serta data arsip perusahaan dengan meminta data yang berkaitan dengan penelitian yang dibahas. Kelima, penelitian kepustakaan dengan cara membaca, menelaah, dan memahami isi literatur dari studi pustaka yang berkaitan dengan analisis biaya-volume-laba berdasarkan Martusa dan Wijaya (2011) dan Utami dan Kuang (2003).

\section{HASIL DAN PEMBAHASAN}

Tabel 1 menujukkan biaya manuaktur PT SD Textile periode 2008-2011. 
Tabel 1 Klasifikasi Biaya Manufaktur PT SD Textile

\begin{tabular}{|c|c|c|c|c|c|c|c|c|}
\hline \multirow{2}{*}{$\begin{array}{r}\text { Biaya Manufaktur } \\
\text { Biaya bahan baku langsung }\end{array}$} & \multicolumn{2}{|r|}{ Periode 2011} & \multicolumn{2}{|c|}{ Periode 2010} & \multicolumn{2}{|c|}{ Periode 2009} & \multicolumn{2}{|c|}{ Periode 2008} \\
\hline & $\mathrm{Rp}$ & $10,283,610,810$ & $\mathrm{Rp}$ & $12,056,116,382$ & $\mathrm{Rp}$ & $9,778,799,882$ & $\mathrm{Rp}$ & $9,655,760,117$ \\
\hline Biaya tenaga kerja langsung & $\mathrm{Rp}$ & $2,991,340,488$ & $\mathrm{Rp}$ & $2,813,547,114$ & $\mathrm{Rp}$ & $2,640,091,053$ & $\mathrm{Rp}$ & $2,489,483,292$ \\
\hline Biaya lembur - TKL & $\mathrm{Rp}$ & $26,164,479$ & $\mathrm{Rp}$ & $24,594,663$ & $\mathrm{Rp}$ & $23,091,312$ & $\mathrm{Rp}$ & $21,729,966$ \\
\hline Biaya bahan pembantu langsung & $\mathrm{Rp}$ & $154,199,183$ & $\mathrm{Rp}$ & $165,926,395$ & $\mathrm{Rp}$ & $150,167,138$ & $\mathrm{Rp}$ & $147,116,338$ \\
\hline Biaya tenaga kerja tidak langsung & $\mathrm{Rp}$ & $753,168,584$ & $\mathrm{Rp}$ & $741,602,421$ & $\mathrm{Rp}$ & $730,563,064$ & $\mathrm{Rp}$ & $720,623,913$ \\
\hline Biaya lembur -TKTL & $\mathrm{Rp}$ & $15,053,323$ & $\mathrm{Rp}$ & $13,483,507$ & $\mathrm{Rp}$ & $11,913,691$ & $\mathrm{Rp}$ & $10,343,875$ \\
\hline Biaya listrik dan air & $\mathrm{Rp}$ & $359,903,893$ & $\mathrm{Rp}$ & $386,718,682$ & $\mathrm{Rp}$ & $349,989,151$ & $\mathrm{Rp}$ & $342,878,758$ \\
\hline Biaya perlengkapan produksi & $\mathrm{Rp}$ & $2,913,026$ & $\mathrm{Rp}$ & $3,134,568$ & $\mathrm{Rp}$ & $3,372,959$ & $\mathrm{Rp}$ & $3,629,481$ \\
\hline Biaya bahan bakar produksi & $\mathrm{Rp}$ & $535,465,893$ & $\mathrm{Rp}$ & $576,189,337$ & $\mathrm{Rp}$ & $521,464,377$ & $\mathrm{Rp}$ & $510,870,288$ \\
\hline Biaya packing & $\mathrm{Rp}$ & $105,715,943$ & $\mathrm{Rp}$ & $113,755,890$ & $\mathrm{Rp}$ & $102,951,652$ & $\mathrm{Rp}$ & $100,860,083$ \\
\hline Biaya pembuangan limbah & $\mathrm{Rp}$ & 442,323 & Rp & 475,963 & $\mathrm{Rp}$ & 430,757 & $\mathrm{Rp}$ & 422,006 \\
\hline Biaya ongkos angkut pembelian & $\mathrm{Rp}$ & $3,373,871$ & $\mathrm{Rp}$ & $3,630,461$ & $\mathrm{Rp}$ & $3,285,650$ & $\mathrm{Rp}$ & $3,218,898$ \\
\hline Biaya pemeliharaan mesin & $\mathrm{Rp}$ & $44,834,738$ & $\mathrm{Rp}$ & $48,244,525$ & $\mathrm{Rp}$ & $51,913,634$ & $\mathrm{Rp}$ & $55,861,790$ \\
\hline Biaya jamsostek & $\mathrm{Rp}$ & $180,527,751$ & $\mathrm{Rp}$ & $169,696,447$ & $\mathrm{Rp}$ & $159,323,752$ & $\mathrm{Rp}$ & $149,930,820$ \\
\hline Biaya overhead lainnya & $\mathrm{Rp}$ & $2,751,862$ & $\mathrm{Rp}$ & $2,961,148$ & $\mathrm{Rp}$ & $3,186,350$ & $\mathrm{Rp}$ & $7,428,679$ \\
\hline Total Biaya Manufaktur & Rp & $15,459,466,167$ & Rp & $17,120,077,503$ & $\mathbf{R p}$ & $14,530,544,422$ & $\mathbf{R p}$ & $14,220,158,304$ \\
\hline
\end{tabular}

Tabel 2 berikut menyajikan data yang berkaitan dalam analisis biaya-volume-laba dengan perhitungan titik impas banyak produk pada PT SD Textile periode 2008-2011.

Tabel 2 Analisis Biaya-Volume-Laba PT SD Textile Periode 2008-2011

\begin{tabular}{lcccc}
\hline Produk & Harga Jual Per unit & Biaya Variabel Per unit & Biaya Tetap & Bauran Penjualan \\
\hline Damask & 115.000 & $58.621,9223$ & & 3.2154 \\
Towel & 105.000 & $59.891,2889$ & 6.429 .768 .285 & 3.1940 \\
Sheet & 102.500 & $81.155,7410$ & & 1.0000 \\
\hline
\end{tabular}

Biaya variabel per rupiah penjualan dapat ditentukan dengan perhitungan berikut ini.

$$
\begin{aligned}
& \mathrm{V}=\frac{\text { Bilaya Vardabel }}{\text { Pendapatan Penjualan }} \\
& V=\frac{(2,2154 \times \operatorname{Rp} 5 R \cdot 621,922,2)+(2,1940 \times \operatorname{Rp} 58.891,28 R Q)+(1,0000 \times \operatorname{Rp} 81.158,7410)}{(3,2154 \times \operatorname{Rp} 115,000)+(3,1940 \times \operatorname{Rp} 105,000)+(1,0000 \times \operatorname{Rp} 102,500)}
\end{aligned}
$$$$
\mathrm{V}=\frac{\operatorname{Rp} 460,939}{\operatorname{Rp} 807,6 \cdot 37}
$$

$\mathrm{V}=\mathrm{Rp}$ 0,5707 per kg.

Titik impas dalam pendapatan penjualan dapat ditentukan dengan perhitungan berikut.

$\mathrm{R}(\mathrm{BE})=\frac{\mathrm{F}}{1-V}=\frac{\mathrm{Rp} 6,429,768,285}{1-0,5707}=\frac{\mathrm{Rp} 6,429,768.285}{0,4293}=\operatorname{Rp} 14.978 .230 .366$.

Titik impas dengan bauran penjualan dapat ditentukan dengan perhitungan: 
$\mathrm{Q}(\mathrm{BE})=\frac{\mathrm{R}(\mathrm{EE})}{\mathrm{Rp} \otimes 07,637}=\frac{\mathrm{Rp} 14,978,230,366}{\mathrm{Rp} 807,637}=18.546$ per $\mathrm{kg}$.

Titik impas untuk masing-masing produk dapat dilakukan dengan perhitungan:

Produk damask $\quad: 18.546$ per $\mathrm{kg} \times$ 3 3,2154 damask per $\mathrm{kg}=59.632 \mathrm{~kg}$ damask.

Produk towel $\quad: 18.546$ per $\mathrm{kg} \times 3,1940$ towel per $\mathrm{kg}=59.235 \mathrm{~kg}$ towel.

Produk sheet $\quad: 18.546$ per $\mathrm{kg} \times 1,0000$ sheet per $\mathrm{kg}=18.546 \mathrm{~kg}$ sheet. berikut:

Hasil perhitungan titik impas pada PT SD Textie periode 2008 dapat dibuktikan sebagai

\section{Penjualan}

Produk Damask (59.632 x Rp 115.000)

Rp 6,857,649,887

Produk Towel (59.235 x Rp 105.000)

Rp 6,219,642,402

Produk Sheet $\quad$ (18.546 x Rp 102.500)

Rp 1,900,938,077

\section{Total Penjualan}

Harga Pokok Penjualan Variabel

Rp 14,978,230,366

Produk Damask (59.632 x Rp 58.621,9223)

Produk Towel $\quad$ (59.235 x Rp 59.891,2889)

Rp 3,495,727,121

Rp 3,547,641,905

Produk Sheet $\quad$ (18.546 x Rp 81.155,7410)

Rp 1,505,093,055

Total HPP Variabel

Margin Kontribusi

Biaya Tetap

Laba Operasi

$\operatorname{Rp} \underline{(8,548,462,081)}$
$\operatorname{Rp} \mathbf{6 , 4 2 9 , 7 6 8 , 2 8 5}$
$\operatorname{Rp} \underline{(6,429,768,285)}$

Hal ini menunjukkan bahwa penjualan perusahaan sudah melewati batas titik impas sebesar Rp4.336.417.134 atau $39.782 \mathrm{~kg}$ dari penjualan aktual perusahaan.

Perhitungan perencanaan laba berdasarkan laba operasi maksimum yang diperoleh PT SD Tetxile pada periode 2008 adalah sebagai berikut. Biaya variabel per rupiah penjualan dapat ditentukan dengan perhitungan:

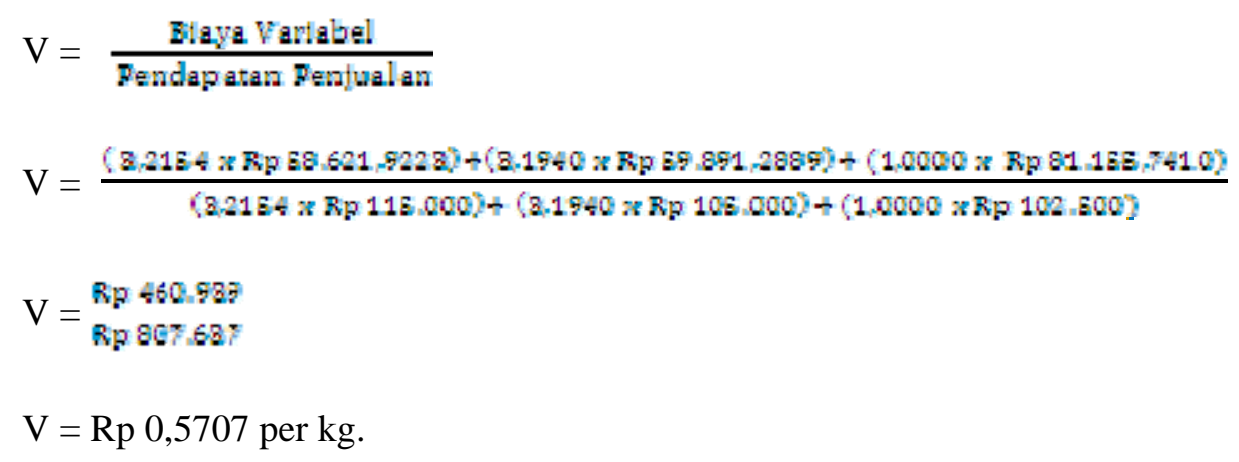

Dengan laba operasi maksimum yang diperoleh PT SD Tetxile sebesar Rp1.861.512.120, maka titik impas dalam pendapatan penjualan dapat ditentukan dengan perhitungan sebagai berikut:

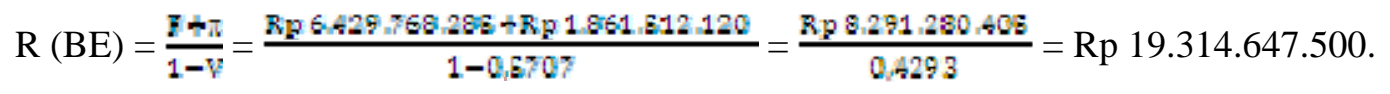


Titik impas dengan bauran penjualan dapat ditentukan dengan perhitungan:

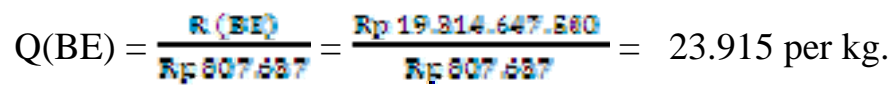

Titik impas untuk masing-masing produk dapat dilakukan dengan perhitungan berikut.

Produk damask $\quad: 23.915$ per $\mathrm{kg} \times 3,2154$ damask per $\mathrm{kg}=76.896 \mathrm{~kg}$ damask.

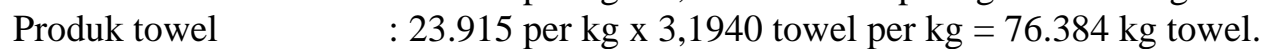

Produk sheet $\quad: 23.915$ per $\mathrm{kg} \times 1,0000$ sheet per $\mathrm{kg}=23.915 \mathrm{~kg}$ sheet.

Hasil perhitungan laba operasi maksimum yang dihasilkan oleh PT S D Textile pada periode 2008 adalah sebagai berikut.

\section{Penjualan}

Produk Damask (76.896 x Rp 125.000)

Produk Towel $\quad$ (76.384 x Rp 107.500)

Produk Sheet $\quad(23.915 \times$ Rp 105.000)

Rp 8,843,040,000

Rp 8,020,320,000

Rp 2,451,287,500

Total Penjualan

Rp 19,314,647,500

Harga Pokok Penjualan Variabel

Produk Damask (76.896 x Rp 58.621,9223)

Produk Towel $\quad$ (76.384 x Rp 59.891,2889)

Rp 4,507,791,338

Rp 4,574,736,212

Produk Sheet $\quad$ (23.915 x Rp 81.155,7410)

Rp 1,940,839,545

Total HPP Variabel

$\mathbf{R p} \underline{(11,023,367,095)}$

Margin Kontribusi

Biaya Tetap

Laba Operasi

Rp 8,291,280,405

Rp $\underline{6,429,768,285)}$

Rp 1,861,512,120

Tabel 3 Perhitungan Titik Impas Multiproduk PT SD Textile Periode 2009

\begin{tabular}{lcccc}
\hline Produk & Harga Jual Per unit & Biaya Variabel Per unit & Biaya Tetap & Bauran Penjualan \\
\hline Damask & 125.000 & $65.010,0211$ & & 2.7774 \\
Towel & 107.500 & $60.380,1548$ & 6.533 .682 .097 & 2.0622 \\
Sheet & 105.000 & $74.364,5596$ & & 1.0000 \\
\hline
\end{tabular}

Titik impas dalam pendapatan penjualan dapat ditentukan dengan perhitungan:

$\mathrm{R}(\mathrm{BE})=\frac{\mathrm{F}}{1-\mathrm{V}}=\frac{\mathrm{Fp} 6,333.582,097}{1-0,5631}=\frac{\mathrm{Rp} 6,533,682,097}{0,4369}=\mathrm{Rp} 14.954 .022 .871$.

Titik impas dengan bauran penjualan dapat ditentukan dengan perhitungan berikut:

$\mathrm{Q}(\mathrm{BE})=\frac{\mathrm{R}(\mathrm{EE})}{\operatorname{Rp} 678,862}=\frac{\operatorname{Rp~} 14,954,022,871}{\operatorname{Rp} 673.862}=22.192$ per kg.

Titik impas untuk masing-masing produk dapat dilakukan dengan perhitungan berikut ini. 
Produk damask

Produk towel

Produk sheet
: 22.192 per $\mathrm{kg}$ x 2,7774 damask per $\mathrm{kg}=61.635 \mathrm{~kg}$ damask.

: 22.192 per $\mathrm{kg} \times 2,0622$ towel per $\mathrm{kg}=45.763 \mathrm{~kg}$ towel.

: 22.192 per $\mathrm{kg} \times 1,0000$ sheet per $\mathrm{kg}=22.192 \mathrm{~kg}$ sheet.

Penjualan perusahaan sudah melewati batas titik impas sebesar Rp5.075.387.850 atau 43.982 kg dari penjualan aktual perusahaan.

Dengan laba operasi maksimum yang diperoleh PT SD Tetxile sebesar Rp2.217.528.424, maka titik impas dalam pendapatan penjualan dapat ditentukan dengan perhitungan berikut:

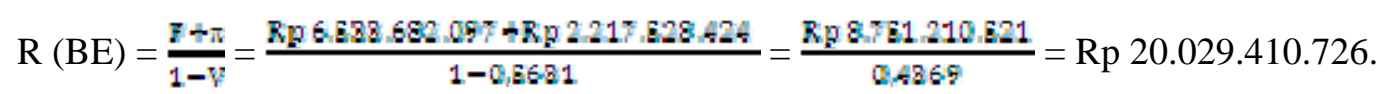

Titik impas dengan bauran penjualan dapat ditentukan dengan perhitungan berikut.

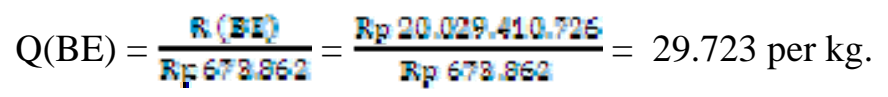

Titik impas untuk masing-masing produk dapat dilakukan dengan perhitungan berikut ini.

Produk damask $\quad: 29.723$ per $\mathrm{kg} \times 2,7774$ damask per $\mathrm{kg}=82.554 \mathrm{~kg}$ damask.

Produk towel $\quad: 29.723$ per $\mathrm{kg} \times 2,0622$ towel per $\mathrm{kg}=61.295 \mathrm{~kg}$ towel.

Produk sheet $\quad: 29.723$ per $\mathrm{kg} \times 1,0000$ sheet per $\mathrm{kg}=29.723 \mathrm{~kg}$ sheet.

Hasil perhitungan laba operasi maksimum yang dihasilkan oleh PT S D Textile pada periode 2009 sebagai berikut:

\begin{tabular}{llll} 
Penjualan & & & \\
Produk Damask & $(82.554 \times$ Rp 125.000) & Rp 10,319,250,000 \\
Produk Towel & $(61.295 \times$ Rp 107.500) & Rp & $6,589,212,500$ \\
Produk Sheet & $(29.723 \times$ Rp 105.000) & Rp $\quad \underline{3,120,948,226}$ \\
\hline
\end{tabular}

Total Penjualan

Harga Pokok Penjualan Variabel

Produk Damask (82.554 x Rp 65.010,0211)

Produk Towel $\quad(61.295 \times$ Rp 60.380,1548)

Produk Sheet $\quad(29.723 \times$ Rp 74.364,5596)

Total HPP Variabel

Margin Kontribusi

Biaya Tetap

Laba Operasi

Rp 20,029,410,726

Rp 5,366,837,280

Rp 3,701,001,588

Rp 2,210,361,337

$\begin{array}{ccc} & \operatorname{Rp} \underline{(11,278,200,205}) \\ & \mathbf{R p} \mathbf{8 , 7 5 1 , 2 1 0 , 5 2 1} \\ & \operatorname{Rp} \underline{6,533,682,097)} \\ \text { Rp } \quad 2,217,528,424\end{array}$

Hal ini menunjukkan bahwa penjualan perusahaan sudah melewati batas titik impas sebesar Rp5.075.387.850 atau $43.982 \mathrm{~kg}$ dari penjualan titik impas perusahaan.

Berdasarkan penjualan PT SD Textile pada periode 2010 sebesar Rp21.931.327.500 yang terdiri dari penjualan produk damask sebesar Rp4.175.207.500 atau $31.511 \mathrm{~kg}$, produk towel sebesar Rp14.058.277.500 atau $110.261 \mathrm{~kg}$, dan produk sheet sebesar Rp3.697.842.500 atau $31.471 \mathrm{~kg}$. Dengan mengetahui volume penjualan dan unit produk yang dijual, maka dapat diketahui harga jual per kg produk damask sebesar Rp132.500, produk towel sebesar Rp127.500, dan produk sheet sebesar Rp117.500. Kemudian biaya variabel untuk masing-masing produk yaitu produk damask sebesar Rp3.735.280.665, produk towel sebesar Rp7.386.924.818, dan produk sheet sebesar Rp2.544.930.062 dengan biaya variabel per unit yaitu produk damask sebesar Rp118.538,9440, produk towel sebesar Rp66.994,9014, dan produk sheet sebesar Rp80.865,8785. Biaya tetap PT SD Tetxile sebesar 
Rp6.854.300.816 dan bauran produk yang dijual antara produk damask, sheet, dan towel yaitu 1.0013 : $3.5036: 1.0000$.

Tabel 4 Perhitungan Titik Impas Multiproduk PT SD Textile Periode 2010

\begin{tabular}{lcccc}
\hline \multicolumn{1}{c}{ Produk } & Harga Jual Per unit & Biaya Variabel Per unit & Biaya Tetap & Bauran Penjualan \\
\hline Damask & 132.500 & $118.538,9440$ & & 1.0013 \\
Towel & 127.500 & $66.994,9014$ & 6.854 .300 .816 & 3.5036 \\
Sheet & 117.500 & $80.865,8785$ & & 1.0000 \\
\hline
\end{tabular}

Titik impas untuk masing-masing produk dapat dilakukan dengan perhitungan sebagai berikut:

Produk damask $\quad: 26.102$ per $\mathrm{kg}$ x 1,0013 damask per $\mathrm{kg}=26.135 \mathrm{~kg}$ damask.

Produk towel $\quad: 26.102$ per $\mathrm{kg} \times 3,5036$ towel per $\mathrm{kg}=91.450 \mathrm{~kg}$ towel.

Produk sheet $\quad: 26.102$ per $\mathrm{kg} \times 1,0000$ sheet per $\mathrm{kg}=26.102 \mathrm{~kg}$ sheet.

Berdasarkan hasil perhitungan, penjualan titik impas yang dicapai PT SD Textile pada periode 2010 sebesar Rp18.189.789.975 atau 143.687 kg terdiri dari produk damask sebesar $26.135 \mathrm{~kg}$ atau Rp3.462.907.000, produk towel sebesar $91.450 \mathrm{~kg}$ atau Rp11.659.901.351, dan produk sheet sebesar $26.102 \mathrm{~kg}$ atau Rp3.066.981.624 dengan laba operasi Rp0.00. Hal ini menunjukkan bahwa penjualan perusahaan sudah melewati batas titik impas sebesar Rp3.741.537.530 atau $29.556 \mathrm{~kg}$ dari penjualan aktual perusahaan.

Perhitungan perencanaan laba berdasarkan laba operasi maksimum yang diperoleh PT Sahid Detolin Tetxile pada periode 2010 sebagai berikut:

Titik impas untuk masing-masing produk dapat dilakukan dengan perhitungan berikut.

Produk damask : 31.471 per $\mathrm{kg} \times 1,0013$ damask per $\mathrm{kg}=31.511 \mathrm{~kg}$ damask.

Produk towel $\quad: 31.471$ per $\mathrm{kg} \times 3,5036$ towel per $\mathrm{kg}=110.261 \mathrm{~kg}$ towel.

Produk sheet $\quad: 31.471$ per $\mathrm{kg} \times 1,0000$ sheet per $\mathrm{kg}=31.471 \mathrm{~kg}$ sheet.

Hasil perhitungan laba operasi maksimum yang dihasilkan oleh PT SD Textile pada periode 2010 adalah sebagai berikut.

\section{Penjualan}

Produk Damask (31.511 x Rp 132.500)

Produk Towel $\quad$ (110.261 x Rp 127.500)

Rp 4,175,207,500

Rp 14,058,277,500

Produk Sheet

(31.471 x Rp 117.500)

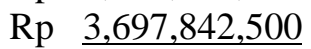

Total Penjualan

Harga Pokok Penjualan Variabel

Produk Damask (31.511 x Rp 118.541,5344)

Produk Towel $\quad$ (110.261 x Rp 66.994,9014)

Produk Sheet $\quad$ (31.471 x Rp 80.865,8785)

Total HPP Variabel

Margin Kontribusi

Biaya Tetap

Laba Operasi

Rp 21,931,327,500

Rp 3,735,280,665

Rp 7,386,924,818

Rp 2,544,930,062

\section{$\operatorname{Rp} \underline{(13,667,135,545)}$ \\ Rp 8,264,191,955 \\ Rp $\underline{6,854,300,816)}$ \\ Rp $\quad 1,409,891,139$}

Berdasarkan hasil perhitungan, maka laba operasi maksimum yang diperoleh PT SD Textile pada periode 2010 sebesar Rp1.409.891.139 dengan tingkat volume penjualan yang dicapai sebesar Rp21.931.327.500 atau 173.243 kg terdiri dari penjualan produk damask sebesar Rp4.175.207.500 atau $31.511 \mathrm{~kg}$, produk towel sebesar Rp14.058.277.500 atau $110.261 \mathrm{~kg}$, dan produk sheet sebesar 
Rp3.697.842.500 atau $31.471 \mathrm{~kg}$. Hal ini menunjukkan bahwa penjualan perusahaan sudah melewati batas titik impas sebesar Rp3.741.537.530 atau $29.556 \mathrm{~kg}$ dari penjualan titik impas perusahaan.

Penjualan PT S D Textile pada periode 2011 sebesar Rp20.460.445.000 yang terdiri dari penjualan produk damask sebesar Rp7.679.200.000 atau $52.960 \mathrm{~kg}$, produk towel sebesar Rp7.777.485.000 atau 58.698 kg, dan produk sheet sebesar Rp5.003.760.000 atau 41.698 kg. Dengan diketahui volume penjualan dan unit produk yang dijual, maka dapat diketahui harga jual per $\mathrm{kg}$ produk damask sebesar Rp145.000, produk towel sebesar Rp132.500, dan produk sheet sebesar Rp120.000. Kemudian, biaya variabel untuk masing-masing produk, yaitu produk damask sebesar Rp4.870.357.548, produk towel sebesar Rp4.945.504.468, dan produk sheet sebesar Rp2.168.938.693; dengan biaya variabel per unit, yaitu produk damask sebesar Rp91.962,9446, produk towel sebesar Rp84.253,3727, dan produk sheet sebesar Rp52.015,4130. Biaya tetap PT SD Tetxile sebesar Rp7.004.049.185 dan bauran produk yang dijual antara produk damask, sheet, dan towel yaitu 1.2701 : $1.4077: 1.0000$.

Titik impas untuk masing-masing produk dapat dilakukan dengan perhitungan sebagai berikut:

Produk damask

Produk towel

Produk sheet
: 34.458 per $\mathrm{kg} \times 1,2701$ damask per $\mathrm{kg}=43.765 \mathrm{~kg}$ damask.

: 34.458 per $\mathrm{kg} \times 1,4077$ towel per $\mathrm{kg}=48.506 \mathrm{~kg}$ towel.

: 34.458 per $\mathrm{kg} \times 1,0000$ sheet per $\mathrm{kg}=34.458 \mathrm{~kg}$ sheet.

Penjualan titik impas yang dicapai PT SD Textile pada periode 2011 sebesar Rp16.907.972.799 atau $126.729 \mathrm{~kg}$ terdiri dari produk damask sebesar $43.765 \mathrm{~kg}$ atau Rp6.345.888.602, produk towel sebesar $48.506 \mathrm{~kg}$ atau Rp6.427.108.737, dan produk sheet sebesar $34.458 \mathrm{~kg}$ atau Rp4.134.975.460 dengan laba operasi Rp0.00. Hal ini menunjukkan bahwa penjualan perusahaan sudah melewati batas titik impas sebesar Rp3.552.472.210 atau 26.627 kg dari penjualan aktual perusahaan.

Perhitungan perencanaan laba berdasarkan laba operasi maksimum yang diperoleh PT SD Tetxile pada periode 2011 sebagai berikut.

Titik impas untuk masing-masing produk dapat dilakukan dengan perhitungan:

Produk damask

Produk towel

Produk sheet
: 41.698 per $\mathrm{kg}$ x 1,2701 damask per $\mathrm{kg}=52.960 \mathrm{~kg}$ damask.

: 41.698 per $\mathrm{kg} \times 1,4077$ towel per $\mathrm{kg}=58.698 \mathrm{~kg}$ towel.

: 41.698 per $\mathrm{kg}$ x 1,0000 sheet per $\mathrm{kg}=41.698 \mathrm{~kg}$ sheet.

Hasil perhitungan laba operasi maksimum yang dihasilkan oleh PT Tolin Textile pada periode 2011 sebagai berikut:

\section{Penjualan \\ Produk Damask $\quad(52.960 \times$ Rp 145.000) \\ Produk Towel $\quad(58.698 \times \mathrm{Rp} 132.500)$ \\ Produk Sheet (41.698 x Rp 120.000) \\ Total Penjualan \\ Harga Pokok Penjualan Variabel}

Produk Damask $\quad$ (52.960 x Rp 91.962,9446)

Produk Towel $\quad(58.698 \times \mathrm{Rp} 84.253,3727)$

Produk Sheet $\quad(41.698 \times$ Rp 52.015,4130)

Total HPP Variabel

Margin Kontribusi

Biaya Tetap

Laba Operasi
Rp 7,679,200,000

Rp 7,777,485,000

Rp 5,003,760,000

Rp 20,460,445,000

Rp4,870,357,548

Rp 4,945,504,468

Rp 2,168,938,693 
Berdasarkan hasil perhitungan, maka laba operasi maksimum yang diperoleh PT SD Textile pada periode 2011 sebesar Rp20.460.445.000 atau 153.356 kg; terdiri dari penjualan produk damask sebesar Rp7.679.200.000 atau $52.960 \mathrm{~kg}$, produk towel sebesar Rp7.777.485.000 atau $58.698 \mathrm{~kg}$, dan produk sheet sebesar Rp5.003.760.000 atau $41.698 \mathrm{~kg}$. Hal ini menunjukkan bahwa penjualan perusahaan sudah melewati batas titik impas sebesar Rp3.552.472.210 atau $26.627 \mathrm{~kg}$ dari penjualan titik impas perusahaan.

Titik impas dengan bauran penjualan dapat ditentukan dengan perhitungan sebagai berikut:

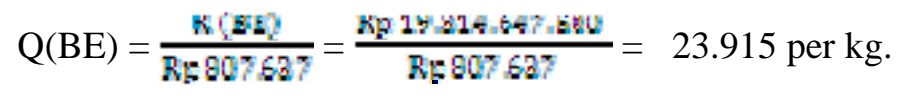

Titik impas untuk masing-masing produk dapat dilakukan dengan perhitungan:

Produk damask $\quad$ : 23.915 per $\mathrm{kg} \times 3$ 3,2154 damask per $\mathrm{kg}=76.896 \mathrm{~kg}$ damask.

Produk towel $\quad: 23.915$ per $\mathrm{kg} \times 3,1940$ towel per $\mathrm{kg}=76.384 \mathrm{~kg}$ towel.

Produk sheet $\quad: 23.915$ per $\mathrm{kg} \times 1,0000$ sheet per $\mathrm{kg}=23.915 \mathrm{~kg}$ sheet.

Hasil perhitungan laba operasi maksimum yang dihasilkan oleh PT SD Textile pada periode 2008 sebagai berikut:

\section{Penjualan}

Produk Damask $(76.896 \times$ Rp 125.000)

Produk Towel $\quad$ (76.384 x Rp 107.500)

Rp 8,843,040,000

Total Penjualan

(23.915 x Rp 105.000) Rp 2,451,287,500

\section{Harga Pokok Penjualan Variabel}

Produk Damask (76.896 x Rp 58.621,9223)

Produk Towel $\quad$ (76.384 x Rp 59.891,2889)

Produk Sheet $\quad(23.915 \times \mathrm{Rp} 81.155,7410)$

Total HPP Variabel

Margin Kontribusi

Biaya Tetap

Laba Operasi

Rp 19,314,647,500

Rp 4,507,791,338

Rp 4,574,736,212

Rp $\underline{1,940,839,545}$

Berdasarkan hasil perhitungan, maka laba operasi maksimum yang diperoleh PT SD Textile pada periode 2008 sebesar Rp 1,861,512,120 dengan tingkat volume penjualan yang dicapai sebesar Rp19.314.647,500 atau $177.195 \mathrm{~kg}$ produk; terdiri dari penjualan produk damask sebesar Rp8.843.040.000 atau 76.896 kg , produk towel sebesar Rp8.020.320.000 atau $76.384 \mathrm{~kg}$, dan produk sheet sebesar Rp2.451.287.500 atau $23.95 \mathrm{~kg}$. Hal ini menunjukkan bahwa penjualan perusahaan sudah melewati batas titik impas sebesar Rp4.336.417.134 atau $39.782 \mathrm{~kg}$ dari penjualan titik impas perusahaan.

Titik impas untuk masing-masing produk dapat dilakukan dengan perhitungan sebagai berikut:

Produk damask $\quad: 22.192$ per $\mathrm{kg} \times 2,7774$ damask per $\mathrm{kg}=61.635 \mathrm{~kg}$ damask

Produk towel $\quad: 22.192$ per $\mathrm{kg} \times 2,0622$ towel per $\mathrm{kg}=45.763 \mathrm{~kg}$ towel.

Produk sheet $\quad: 22.192$ per $\mathrm{kg} \times 1,0000$ sheet per $\mathrm{kg}=22.192 \mathrm{~kg}$ sheet.

Penjualan titik impas yang dicapai PT SD Textile pada periode 2009 sebesar Rp 14.954.022.871 atau $129.590 \mathrm{~kg}$ terdiri dari produk damask sebesar $61.635 \mathrm{~kg}$ atau Rp 7,704,385,447, produk towel sebesar45.763 $\mathrm{kg}$ atau Rp 4,919,527,378, dan produk sheet sebesar $22.192 \mathrm{~kg}$ atau Rp 
2,330,110,046 dengan laba operasi Rp 0.00. Hal ini menunjukkan bahwa penjualan perusahaan sudah melewati batas titik impas sebesar Rp 5.075.387.850 atau $43.982 \mathrm{~kg}$ dari penjualan aktual perusahaan.

Titik impas untuk masing-masing produk dapat dilakukan dengan perhitungan sebagai berikut:

Produk damask $\quad: 29.723$ per $\mathrm{kg}$ x 2,7774 damask per $\mathrm{kg}=82.554 \mathrm{~kg}$ damask.

Produk towel $\quad: 29.723$ per $\mathrm{kg} \times 2,0622$ towel per $\mathrm{kg}=61.295 \mathrm{~kg}$ towel.

Produk sheet $\quad: 29.723$ per $\mathrm{kg} \times 1,0000$ sheet per $\mathrm{kg}=29.723 \mathrm{~kg}$ sheet.

Hasil perhitungan laba operasi maksimum yang dihasilkan oleh PT SD Textile pada periode 2009 sebagai berikut:

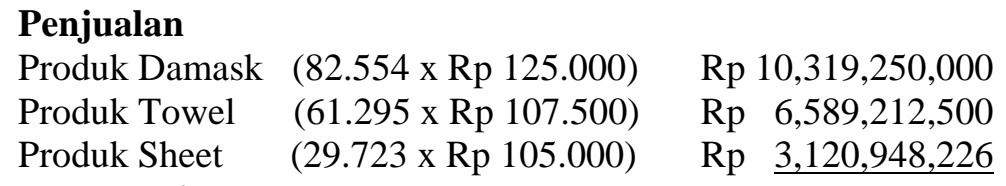

Total Penjualan

Harga Pokok Penjualan Variabel

Rp 20,029,410,726

Produk Damask (82.554 x Rp 65.010,0211)

Produk Towel $\quad(61.295 \times$ Rp 60.380,1548)

Produk Sheet $\quad(29.723 \times \mathrm{Rp} 74.364,5596)$

Total HPP Variabel

Margin Kontribusi

Biaya Tetap

Laba Operasi

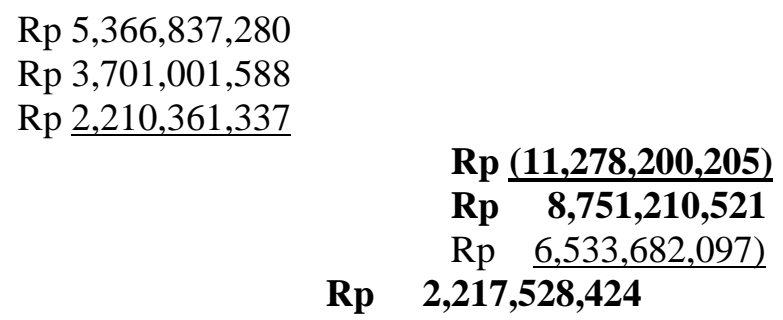

Hal ini menunjukkan bahwa penjualan perusahaan sudah melewati batas titik impas sebesar Rp5.075.387.850 atau $43.982 \mathrm{~kg}$ dari penjualan titik impas perusahaan

Diketahui bahwa penjualan PT SD Textile pada periode 2010 sebesar Rp21.931.327.500 yang terdiri dari penjualan produk damask sebesar Rp4.175.207.500 atau $31.511 \mathrm{~kg}$, produk towel sebesar Rp14.058.277.500 atau $110.261 \mathrm{~kg}$, dan produk sheet sebesar Rp3.697.842.500 atau $31.471 \mathrm{~kg}$. Dengan diketahui volume penjualan dan unit produk yang dijual, maka dapat diketahui harga jual per kg produk damask sebesar Rp132.500, produk towel sebesar Rp127.500, dan produk sheet sebesar Rp117.500. Kemudian, biaya variabel untuk masing-masing produk, yaitu produk damask sebesar Rp3.735.280.665, produk towel sebesar Rp7.386.924.818, dan produk sheet sebesar Rp2.544.930.062 dengan biaya variabel per unit, yaitu produk damask sebesar Rp118.538,9440, produk towel sebesar Rp66.994,9014, dan produk sheet sebesar Rp80.865,8785. Biaya tetap PT SD Tetxile sebesar Rp6.854.300.816 dan bauran produk yang dijual antara produk damask, sheet, dan towel yaitu 1.0013 : $3.5036: 1.0000$.

Titik impas untuk masing-masing produk dapat dilakukan dengan perhitungan sebagai berikut:

Produk damask $\quad: 26.102$ per $\mathrm{kg} \times 1,0013$ damask per $\mathrm{kg}=26.135 \mathrm{~kg}$ damask.

Produk towel $\quad: 26.102$ per $\mathrm{kg} \times 3,5036$ towel per $\mathrm{kg}=91.450 \mathrm{~kg}$ towel.

Produk sheet $\quad$ : 26.102 per $\mathrm{kg} \times 1,0000$ sheet per $\mathrm{kg}=26.102 \mathrm{~kg}$ sheet.

Berdasarkan hasil perhitungan, maka penjualan titik impas yang dicapai PT SD Textile pada periode 2010 sebesar Rp18.189.789.975 atau $143.687 \mathrm{~kg}$; terdiri dari produk damask sebesar 26.135 kg atau Rp3.462.907.000, produk towel sebesar $91.450 \mathrm{~kg}$ atau Rp11.659.901.351, dan produk sheet sebesar $26.102 \mathrm{~kg}$ atau Rp3.066.981.624 dengan laba operasi Rp0.00. Hal ini menunjukkan bahwa penjualan perusahaan sudah melewati batas titik impas sebesar Rp3.741.537.530 atau $29.556 \mathrm{~kg}$ dari penjualan aktual perusahaan. 
Perhitungan perencanaan laba berdasarkan laba operasi maksimum yang diperoleh PT S D Tetxile pada periode 2010 sebagai berikut.

Titik impas untuk masing-masing produk dapat dilakukan dengan perhitungan:

Produk damask $\quad: 31.471$ per $\mathrm{kg} \times 1,0013$ damask per $\mathrm{kg}=31.511 \mathrm{~kg}$ damask

Produk towel $\quad: 31.471$ per $\mathrm{kg} \times 3,5036$ towel per $\mathrm{kg}=110.261 \mathrm{~kg}$ towel.

Produk sheet $\quad: 31.471$ per $\mathrm{kg} \times 1,0000$ sheet per $\mathrm{kg}=31.471 \mathrm{~kg}$ sheet.

Hasil perhitungan laba operasi maksimum yang dihasilkan oleh PT SD Textile pada periode 2010 sebagai berikut:

\section{Penjualan}

Produk Damask (31.511 x Rp 132.500)

Produk Towel $\quad$ (110.261 x Rp 127.500)

Produk Sheet (31.471 x Rp 117.500)

Total Penjualan

\section{Harga Pokok Penjualan Variabel}

Produk Damask (31.511 x Rp 118.541,5344)

Produk Towel $\quad$ (110.261 x Rp 66.994,9014)

Produk Sheet $\quad$ (31.471 x Rp 80.865,8785)

Total HPP Variabel

Margin Kontribusi

Biaya Tetap

Laba Operasi
Rp 4,175,207,500

Rp 14,058,277,500

Rp 3,697,842,500

Rp 21,931,327,500

Rp 3,735,280,665

Rp 7,386,924,818

Rp 2,544,930,062

Berdasarkan hasil perhitungan, maka laba operasi maksimum yang diperoleh PT SD Textile pada periode 2010 sebesar Rp1.409.891,139 dengan tingkat volume penjualan yang dicapai sebesar Rp21.931.327.500 atau 173.243 kg; terdiri dari penjualan produk damask sebesar Rp4.175.207.500 atau $31.511 \mathrm{~kg}$, produk towel sebesar Rp14.058.277.500 atau $110.261 \mathrm{~kg}$, dan produk sheet sebesar Rp3.697.842.500 atau $31.471 \mathrm{~kg}$. Hal ini menunjukkan bahwa penjualan perusahaan sudah melewati batas titik impas sebesar Rp3.741.537.530 atau $29.556 \mathrm{~kg}$ dari penjualan titik impas perusahaan.

Diketahui bahwa penjualan PT SD Textile pada periode 2011 sebesar Rp20.460.445.000, yang terdiri dari penjualan produk damask sebesar Rp7.679.200.000 atau $52.960 \mathrm{~kg}$, produk towel sebesar Rp7.777.485.000 atau $58.698 \mathrm{~kg}$, dan produk sheet sebesar Rp5.003.760.000 atau $41.698 \mathrm{~kg}$. Dengan diketahui volume penjualan dan unit produk yang dijual, maka dapat diketahui harga jual per kg produk damask sebesar Rp145.000, produk towel sebesar Rp132.500, dan produk sheet sebesar Rp120.000. Kemudian, biaya variabel untuk masing-masing produk, yaitu produk damask sebesar Rp4.870.357.548, produk towel sebesar Rp4.945.504.468, dan produk sheet sebesar Rp2.168.938.693; dengan biaya variabel per unit yaitu produk damask sebesar Rp91.962,9446, produk towel sebesar Rp84.253,3727, dan produk sheet sebesar Rp52.015,4130. Biaya tetap PT SD Tetxile sebesar Rp7.004.049.185 dan bauran produk yang dijual antara produk damask, sheet, dan towel yaitu 1.2701 : $1.4077: 1.0000$.

Titik impas untuk masing-masing produk dapat dilakukan dengan perhitungan sebagai berikut:

Produk damask

Produk towel

Produk sheet
: 34.458 per $\mathrm{kg}$ x 1,2701 damask per $\mathrm{kg}=43.765 \mathrm{~kg}$ damask.

: 34.458 per $\mathrm{kg} \times 1,4077$ towel per $\mathrm{kg}=48.506 \mathrm{~kg}$ towel.

: 34.458 per $\mathrm{kg} \times 1,0000$ sheet per $\mathrm{kg}=34.458 \mathrm{~kg}$ sheet.

Penjualan titik impas yang dicapai PT SD Textile pada periode 2011 sebesar Rp16.907.972.799 atau $126.729 \mathrm{~kg}$; terdiri dari produk damask sebesar $43.765 \mathrm{~kg}$ atau 
Rp6.345.888.602, produk towel sebesar $48.506 \mathrm{~kg}$ atau Rp6.427.108.737, dan produk sheet sebesar $34.458 \mathrm{~kg}$ atau Rp4.134.975.460 dengan laba operasi Rp0.00. Hal ini menunjukkan bahwa penjualan perusahaan sudah melewati batas titik impas sebesar Rp3.552.472.210 atau $26.627 \mathrm{~kg}$ dari penjualan aktual perusahaan.

Titik impas untuk masing-masing produk dapat diperoleh sebagai berikut:

Produk damask $\quad$ : 41.698 per $\mathrm{kg} \times 1,2701$ damask per $\mathrm{kg}=52.960 \mathrm{~kg}$ damask.

Produk towel $\quad: 41.698$ per $\mathrm{kg} \mathrm{x} 1,4077$ towel per $\mathrm{kg}=58.698 \mathrm{~kg}$ towel.

Produk sheet $\quad: 41.698$ per $\mathrm{kg} \times 1,0000$ sheet per $\mathrm{kg}=41.698 \mathrm{~kg}$ sheet.

Hasil perhitungan laba operasi maksimum yang dihasilkan oleh perusahaanpada periode 2011 sebagai berikut:

\author{
Penjualan \\ Produk Damask $\quad$ (52.960 x Rp 145.000) \\ Produk Towel $\quad$ (58.698 x Rp 132.500) \\ Produk Sheet $\quad$ (41.698 x Rp 120.000) \\ Rp 7,679,200,000
Rp 7,777,485,000
Rp $\underline{5,003,760,000}$
}

Total Penjualan

Harga Pokok Penjualan Variabel

Produk Damask $\quad$ (52.960 x Rp 91.962,9446)

Produk Towel $\quad$ (58.698 x Rp 84.253,3727)

Produk Sheet $\quad$ (41.698 x Rp 52.015,4130)

Total HPP Variabel

Margin Kontribusi

Biaya Tetap

Laba Operasi
Rp 20,460,445,000

Berdasarkan hasil perhitungan, maka laba operasi maksimum yang diperoleh pada periode 2011 sebesar Rp20.460.445.000 atau $153.356 \mathrm{~kg}$; terdiri dari penjualan produk damask sebesar Rp7.679.200.000 atau 52.960 kg, produk towel sebesar Rp7.777.485.000 atau $58.698 \mathrm{~kg}$, dan produk sheet sebesar Rp5.003.760.000 atau $41.698 \mathrm{~kg}$. Hal ini menunjukkan bahwa penjualan perusahaan sudah melewati batas titik impas sebesar Rp3.552.472.210 atau $26.627 \mathrm{~kg}$ dari penjualan titik impas perusahaan.

\section{SIMPULAN}

Berdasarkan hasil penelitian yang dilakukan dapat disimpulkan sebagai berikut. Pertama, PT SD Textile melakukan klasifikasi biaya berdasarkan produk yang terdiri dari biaya manufaktur dan beban operasi dengan format laporan laba-rugi pendekatan tradisional. Biaya manufaktur PT SD Textile terdiri dari biaya bahan baku langsung, tenaga kerja langsung, dan factory overhead. Beban operasi PT SD Tetxile terdiri dari biaya pemasaran, biaya umum dan administrasi, dan biaya selisih kurs. Akan tetapi, klasifikasi biaya yang dilakukan belum tepat karena terdapat tiga unsur biaya yaitu biaya bunga, biaya selisih kurs, dan biaya pajak dimasukkan ke beban operasional perusahaan. Ketiga unsur biaya tersebut termasuk beban di luar operasional perusahaan dan tidak memengaruhi laba operasi perusahaan.

Kedua, hasil pengubahan format laporan laba-rugi pendekatan tradisional menjadi pendekatan kontribusi pada periode 2008-2011 menunjukkan bahwa tidak terdapat perbedaan laba operasi pada format laporan laba-rugi pendekatan tradisional dan pendekatan kontribusi. Hal ini menunjukkan bahwa unit produksi dan unit penjualan PT SD Textile sama. Dengan demikian, tidak terdapat FOH 
tetap yang dibebankan dan FOH tetap yang dilepaskan. Perbedaannya hanya terletak pada pembebanan nilai factory overhead tetap.

Ketiga, hasil dari perhitungan analisis biaya-volume-laba adalah: (1) hasil analisis biayavolume-laba dengan perhitungan titik impas multiproduk pada periode 2008 sampai periode 2011 menunjukkan bahwa tingkat volume penjualan dan unit produk PT SD Textile sudah mencapai batas titik impas. Penjualan titik impas yang dicapai perusahan pada periode 2008 sebesar Rp14.978.230.366 atau $137.412 \mathrm{~kg}$ produk, periode 2009 sebesar Rp14.954.022.871 atau sebanyak $129.590 \mathrm{~kg}$ produk, periode 2010 sebesar Rp18.189.789.975 atau sebanyak $143.687 \mathrm{~kg}$ produk, dan periode 2011 sebesar Rp16.907.972.799 atau sebanyak 126.729 kg produk. (2) Hasil perhitungan margin kontribusi dan rasio margin kontribusi yang diperoleh pada periode 2008-2011 menunjukkan bahwa perusahaan telah menghasilkan margin kontribusi yang dapat menutup biaya tetap dan menghasilkan laba maksimum. Margin kontribusi dan rasio margin kontribusi yang diperoleh perusahaan pada periode 2008 sebesar Rp8.291.280.405 atau 42,93\%, pada periode 2009 sebesar Rp8.751.210.521 atau 43,69 \%, pada periode 2010 sebesar Rp8.264.191.955 atau 37,68 \%, dan pada periode 2011 sebesar Rp8.475.644.291 atau 41,42 \%. (3) Hasil perhitungan margin pengaman dan rasio margin pengaman yang diperoleh pada periode 2008 sampai periode 2011 menunjukkan bahwa perusahaan sudah melewati batas aman dari penjualan aktual yang diperoleh perusahaan. Hal ini berarti perusahaan sudah melewati batas titik impas dengan memperoleh laba operasi maksimum pada periode 2008 sampai periode 2011. (4) Hasil perhitungan degree of operating leverage (DOL) pada periode 2008 sampai periode 2011, yaitu DOL pada periode 2008 sebesar 4.45, DOL pada periode 2009 sebesar 3.95, DOL pada periode 2010 sebesar 5.86, dan DOL pada periode 2011 sebesar 5.76. Hal ini berarti jika penjualan meningkat 15\%, laba pada periode 2008 sampai periode 2011 akan mengalami peningkatan sebesar $66.75 \%$ pada periode 2008 , $59.25 \%$ pada periode 2009 , $87.9 \%$ pada periode 2010, dan $86.4 \%$ pada periode 2011 .

Keempat, perencanaan laba operasi dengan analisis biaya-volume-laba menggunakan perhitungan titik impas multiproduk pada periode 2012 berdasarkan peningkatan harga jual 5\%, biaya variabel 10\%, biaya tetap 5\%, dan laba operasi 20\% dari periode 2011 dengan bauran penjualan 1.6268 : 1.6352 : 1.0000 menunjukkan bahwa perusahaan harus melakukan tingkat volume penjualan sebesar Rp19.404.311.661 atau sebanyak $137.566 \mathrm{~kg}$ untuk mencapai batas titik impas dan melakukan tingkat volume penjualan sebesar Rp24.063.704.587 atau sebanyak $170.598 \mathrm{~kg}$ produk untuk mencapai laba operasi maksimum yang diharapkan.

\section{Saran}

Berdasarkan simpulan, saran yang dapat diberikan kepada PT S D Textile sebagai berikut. Pertama, sebaiknya alokasi biaya yang tepat dilakukan dalam melakukan klasifikasi biaya yang terdiri dari biaya manufaktur, beban operasi, dan beban di luar operasional perusahaan dalam membuat laporan laba-rugi pendekatan tradisional. Kedua, sebaiknya mengubah laporan laba-rugi pendekatan tradisional menjadi pendekatan kontribusi. Hal ini dilakukan untuk keperluan tujuan pelaporan internal perusahaan sehingga memudahkan perusahaan mengetahui perubahan volume kegiatan dalam perencanaan laba dan pengambilan keputusan. Ketiga, dengan diterapkan analisis biaya-volume-laba dengan perhitungan titik impas multiproduk dapat diketahui volume penjualan minimum yang harus dicapai perusahaan agar mencapai batas titik impas dan membuat perencanaan laba untuk memperoleh laba operasi maksimum yang diharapkan. Keempat, perusahaan juga sebaiknya melakukan perhitungan lainnya yang berkaitan dengan analisis biaya-volume-laba, seperti (a) margin kontribusi dan rasio margin kontribusi menunjukkan jumlah dan persentase yang tersisa dari selisih penjualan dan biaya variabel untuk menutup biaya tetap dan menghasilkan laba, (b) margin pengaman dan rasio margin pengaman untuk menunjukkan seberapa besar penjualan baik dalam rupiah penjualan, unit produk, maupun presentase boleh turun sampai mencapai titik impas atau sebelum kerugian terjadi, (c) degree of operating leverage (DOL) untuk menunjukkan tentang perubahan persentase penjualan perusahaan akan memengaruhi laba perusahaan. 


\section{DAFTAR PUSTAKA}

Carter, W. K., and Usry, M. F. Alih bahasa oleh Krista. (2005). Akuntansi Biaya Buku 2 (edisi 13). Jakarta: Salemba Empat.

Hilton, R. W. (2002). Managerial Accounting: Creating Value in a Dynamic Business Environment. New York: McGraw-Hill.

Martusa, R., dan Wijaya, V. (2011). Peranan analisis cost-volume-profit dalam upaya merencanakan laba perusahaan. Jurnal Ilmiah Akuntansi, 4(2), pp 1-20.

Shim, J. K., and Siegel, J. G. (2009). Budgeting Basics and Beyond ( $3^{\text {rd }}$ ed). Canada: John Wiley \& Sons.

Utami, W. M. P., dan Kuang, T. M. (2003). Aplikasi cost-volume-profit analysis sebagai alat perencanaan laba jangka pendek (regression method). Jurnal Ilmiah Akuntansi, 2(2), pp 1-19. 